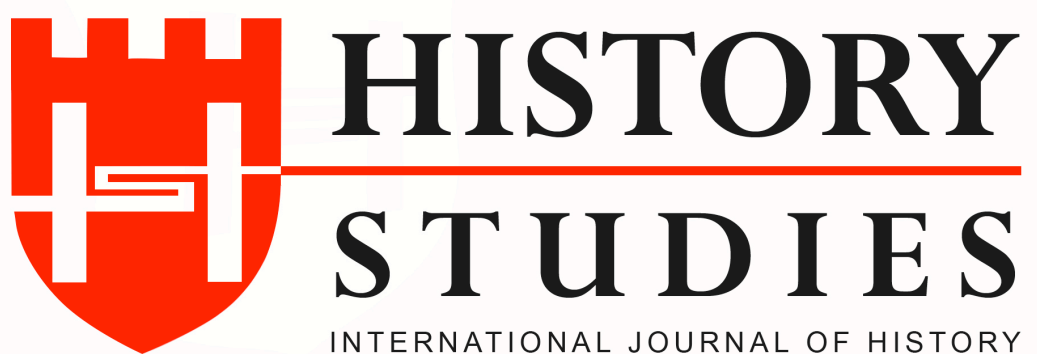

\author{
ISSN: 13094173 (Online) 1309 - 4688 (Print) \\ Volume 11 Issue 4, August 2019 \\ DOI Number: 10.9737/hist.2019.756 \\ Araştırma Makalesi
}

Makalenin Geliş Tarihi: 14.05.2019 Kabul Tarihi: 31.05.2019

Atıf Künyesi: Meltem Akıncı, “Pax Khazarica”, History Studies, 11/4, Ağustos 2019, s. 1123-1135.

\title{
PAX KHAZARICA
}

\section{Pax Khazarica}

\section{Meltem AKINCI}

ORCID No: 0000-0003-0807-1113

Akdeniz Üniversitesi- Antalya

\begin{abstract}
Öz: Ortaçağ Doğu Avrupa Türk tarihi için ayrı bir yere sahip olan Hazar Hakanlı̆̆ı'nın tarihinin aydınlatılması sadece Türkler açısından değil, Hazar etrafında geçmişi şekillenmiş birçok millet için de oldukça önemlidir. Öyle ki bugün Rusların, Bulgarların, Macarların, Arapların geçmişinde Hazarlar kilit pozisyonunda rol oynamıştır. Peki, döneminin büyük güçleri ve inatçı göçebe topluluklarıyla yüzyıllar boyunca aynı sahada yaşamayı başarmış olan Hazar Hakanlığı, oldukça geniş etnik yelpazeye sahip halkını bir arada tutmayı nasıl başarmıştır? İşte bu başarıya XIX. yüzyılda bazı tarihçiler "Pax Khazarica" ibaresini yakıştırmayı uygun görmüştür. Genel itibariyle Hazarların hakim oldukları sahada uygulamış oldukları müsamaha politikası anlamına gelen "Pax Khazarica"nın, Hazarlar nezdinde yürütülmesinin ise çeşitli sebepleri olmuştur. Bu sebepler ise askeri, siyasi ve en önemlisi ekonomik çıkarlara dayanmıştır.
\end{abstract}

Anahtar Kelimeler: Hazar Hakanlığı, Pax Khazarica, Hazar, Barış.

Abstract: The history of the Khazar Khaganate, which has a distinctive place for the Middle Ages Eastern Europe Turkish history, is very important for many nations whose history has been shaped not only in terms of Turks but also in the vicinity of the Caspian. So much so that today, the Russians, Bulgarians, Hungarians, Arabs in the past, the Khazars took a key position. So how did Khazar Khaganate, who had managed to live in the same field for centuries with the great powers and stubborn nomadic communities of his time, managed to keep his multiethnic people together? Here, in the 19th century, some historians have considered it as "Pax Khazarica". In genereal, Pax Khazarica, which means the policy of tolerance applied in the area dominated by Khazars, has been applied by the Khazar Khaganate for various reasons. These reasons were based on military, political and, most importantly, economic interests.

Keywords: Khazar Khaganate, Pax Khazarica, Caspian, Peace.

\section{Giriş}

VII-X. yüzyıl boyunca Aral'dan Dnyester'e kadar olan sahada hâkimiyet kurmayı başarmış olan Hazarlar, günümüzde genellikle Musevilik dinini kabul etmiş olması hasebiyle ön plana çıkartılmaktadır. Oysaki bu Türk devletini daha tanınır kılması gereken bir başka husus vardır ki, o da bu devletin asırlar boyunca nasıl hayatta kalabilmiş olduğuyla alakalıdır. Hazarlar hâkim oldukları sahada yaşayan halkların dini ya da fikrî tercihlerine karışmamış, kendi inançlarını onlara dayatmamış ve bu halkların ekonomik uğraşları üzerinde bir baskı uygulamamıştır. Hazarların hâkim olduğu sahanın genişliği ve bu sahada yaşayan insanların 
etnik çeşitliliğin oldukça renkli olduğu düşünüldüğünde, emperyal rejim ile idare edilen bir devlet sistemi akla gelmektedir. Fakat Hazar Hakanlı̆̆ı'nın idare anlayışı emperyal bir rejime dayanmamış, yönetim sistemleri Ortaçağ devletlerine kıyasla zulme dayanmadan kalıcılığı esas almıştır. Bu siyasi rejime XIX. yüzyıldan beridir bazı tarihçiler "Pax Khazarica" demiş; ve Hazarları diğer konar-göçer kavimlerden ayrı bir yere oturtmuşlardır. Pax Khazarica denilen bu politika, Hazarlar tarafından muayyen sebepler dolayısıyla yürütülmüş ve sonrasında da işlerlik kazanmıştır.

\section{Pax Khazarica Tabirinin Ortaya Çıkışı}

Latince "barış" anlamına gelen "pax"1, siyasi bir terim olarak ilk kez Roma tarihinde karşımıza çıkmaktadır. Bir sükûnet dönemi olarak da izah edilebilecek olan "Pax Romana" İmparator Augustus Caesar'ın M. Ö. 27'de iç karışıklıkların ve iç savaşın bitimiyle Roma hukuk sistemi çerçevesinde ilan ettiği ve M. S. 180-192'de sona erdiği düşünülen barış sürecine verilen isimdir. Bu dönemde Roma topraklarında barış tamamen hâkim olmamış olsa da, çatışmalar Roma lehine sonuçlanmış; ticaret aksamadan devam edebilmiştir. Kimilerine göre diğer insanlar sanatlarda ya da astronomi üzerinde uzmanlaşırken, Romalıların görevini milletleri yönetmek ve insanoğluna, ezilmişi korumaları ve mağrur ile mücadele etmeleri anlamına gelen barış alışkanlığını öğretmek oluşturmuştur. Fakat Roma'da barışın kendisi, savaşın yokluğu anlamına gelmemiştir. Barışı korumak için, askeri gücün varlığı yadsınamaz bir gereklilik doğurmuştur. Roma'da "pax" ifadesi, günümüzde kullanıldığından çok farklı bir anlama ev sahipliği yapmıştır. Bu durum gayet doğaldır, zira değişen toplumlarla birlikte sözcüklerin ihtivası ve bu ihtivaya olan bakış açısı da değişime uğramıştır. Pax, Roma'nın emperyal döneminin egemenlik simgesi olarak kayıtlara geçmiştir. "Roma Barış1/Pax Romana" her ne kadar Augusta'nın sivil savaşları önlemek amacıyla ortaya atmış olduğu bir olgu olsa da, uzun yıllar Roma sınırında devam eden savaşların ya da iç çekişmelerin dengelenmiş bir ekonomiyle dizginlenmesine vesile olmuştur. Roma imparatorları barışı, şiddeti kaldırarak değil onu yöneterek, sosyal sınıflar ve şehirlerarasındaki rekabeti kullanarak ülkelerini uzun süre yönetebilmişlerdir ${ }^{2}$.

Hazarlar için kullanılan "Pax" terimi ise daha çok XIX. yüzyıldan itibaren tarihçilerin kaleminde yer edinmeye başlamıştır. Roma için kullanılan "Pax" terimiyle benzeşse de Roma ve Hazar Devletleri'nin hem coğrafyası hem de tarihi ekonomik, sosyal ve siyasi yöntem açısından farklılıklar arz etmiştir. Hazarlar, çevre halklara emperyal bir bakış açısıyla yaklaşmamış, onlar üzerinde misyonerlik faaliyetleri yürütmemiştir. Bunun dişında "pax" terimi Hazarların kendileri tarafindan yürütmüş oldukları politikalara verilen bir isim olmamış, sonradan bu devlete atfedilen bir hususu oluşturmuştur.

"Pax Khazarica" tabirinin ortaya atılmasından önce Avrupalı tarihçilerin göçebe kavimlerin kültürel ve politik etkilerine karşı her zaman önyargılı ve negatif yaklaşımları olmuştur. XIX. yüzyıl ve XX. Yüzyılın duayen Rus tarihçilerinden olan Sergey Mihaloviç Solovyev (18201879) ve Vasily Klyuçevskiy (1841-1911) Rus tarihini barbarlara karşı Avrupa'nın koruyucusu ve steplere (göçebeler, Asyalılar) karşı orman kavimlerinin (Slavlar, Avrupalılar) savunucusu olarak ifade etmiştir. Fakat Klyuçevskiy "Kurs Russkoy İstorii"3 (Rus Tarihi’nin Seyri) ve

\footnotetext{
${ }^{1}$ Sina Kabaağaç- Erdal Alova, Latince Türkçe Sözlük, Sosyal Yayınları, 1995, s. 424.

${ }^{2}$ Greg Woolf, "Roman Peace", War and Society in the Roman World, Vol. 5, London-Newyork 2002, s.190-191; Brian Campbell, "Roma Dünyasında Diplomasi (Yaklaşık M. Ö. 500- M. S. 235)", Çev: Recep Özman, Tarih Okulu, İlkbahar-Yaz 2013, S. XIV, s. 202-203.

${ }^{3}$ Vasily Klyuçevskiy, Kurs russkoy istorii, T. I., 1990, s. 280.

Klyuçevskiy'in bu eseri için bk: http://www.kulichki.com/inkwell/text/special/history/kluch/kluchlec.htm, https://history.wikireading.ru/92465, (E. T. 12. 5. 2019)
} 
“İstoriya Sosloviy v Rossii”" (Rusya'da Sınıfların Tarihi) adlı eserlerinde Hazar Hakanlığı'na karşı pozitif bir yaklaşım sergilemiştir. O, Hazar hâkimiyetinin Dnyeper Slavlarının endüstriyel başarılarında yararlı bir etkiye sahip olduklarını savunmuştur. Barışçıl politikalar güden Hazarlar, Slavlara Hazar ve Karadeniz pazarlarına ulaşım imkânı sağlamıştır. Benzer bir pozitif yaklaşımı Ukraynalı tarihçi Mihaylo Gruşevskiy de (1866-1934) sergilemiş; onları Asya ordularına karşı Doğu Avrupa'nın savunma duvarı olarak nitelemiştir. ${ }^{5}$ Bu görüş Rus Ortaçağcısı Matvey Kuz'miç Lyubavskiy (1860-1936) tarafindan da paylaşılmıştır. ${ }^{6}$ Hazarlara karşı başlatılan bu 1lımlı yaklaşım, Avrasyacı okulun tipik bir örneği olmakla birlikte, Sovyet dönemi bilginleri tarafindan da kabul görmüştür. Yuriy Vladimiroviç Got'ye (Gauthier) (18731943), "Hazar Kültürü"7 başlıklı makalesinde, Hazarları sadece birer fatih olarak sunmamış, onları bölgede "Pax Khazarica" yani hoşgörü politikası güdenler olarak nitelemiştir. Hazarlara karşı bu iyi niyetli görüş, birçok Rus ve Ukraynalı ilim adamı tarafından savunulmuştur. Fakat her ne kadar bazı ilim adamları tarafindan Hazarlara karşı bu tarz olumlu roller biçilmesine rağmen, genel olarak XIX-XX. yüzyıl ve sonrasında Sovyet tarihçileri için Doğu Slavlarının tarihinde göçebelerin rolünün değerlendirilmesi hep olumsuz olmuştur. ${ }^{8}$

"Pax Khazarica" tabirini kullanan birçok tarihçi olmuştur. Bunlardan biri olan A. Zajaczkowski (1903-1970) "Pax Khazarica"yı Hazarlarda dini hoşgörünün kökleşmesine de zemin hazırlayan ve büyük önem taşıyan bir iç politika olarak tanımlamıştır. Ona göre fethedilen halklara ve onların inançlarına karşı 1lımlı ve liberal bir politika güden Hazarlar, Kırım'dan Yayık Nehri'ne kadar bilinen bir doğal sınırı olmayan güçlü bir imparatorluk yaratmayı ve korumayı başarmıştır. Hazarların en iyi savunma araçları ise Hazar Denizi'nden Dnyeper'e ve Kafkas dağlarından Orta Rusya'nın ormanlarına kadar hâkim olan iç politikaları "Pax Khazarica" olmuştur." Yaratıcısı bilinmeyen "Pax Khazarica" tabiri ünlü Türkolog O. Pritsak (1919-2006) tarafından da kullanılmıştır. Pritsak, eserinde Hazarları anlatırken bu tabiri daha çok "Turkic-Khazar Pax" şeklinde kullanmış; ve bu tabire daha çok Hazarların hükmettiği sahaya atfedilen genel bir ifade anlamı kazandırmıştır. Örneğin o, Hazarların şehirlerini ele alırken Pax Khazarica'yı şu şekilde kullanmıştır:

"Türk/Hazar Barışı (Turkic-Khazar Pax) üç büyük şehre sahip olmuştur. İlk şehir İtil’in aşağısında Doğu Iranlıların bölgesindeki "Khwalis"; onun ikiz şehri ise "Sariycin-Khanlikh" diye de adlandirllan "Atil"'dir. 722-723 yılındaki felaketten sonra, Hazarların başkenti bu ikiz şehre taşınmıştır. Batı şehri olan Amol ya da Sariycin, devletin ve inançların merkezi haline gelmiştir. Atil ya da Khamlikise ticaret bölgesi haline gelmiştir."

Pritsak, Hazarlarda "pax'ın” il-teber unvanlı bir kral tarafından idare edildiğini, şehirlere ve bağlı diğer birimlere ek olarak Hazar Barış1/Khazar Pax'ın kendine bağlı birkaç halkı da içerdiğini (Sever, Ventic, Ar, Ves, Çeremiş vb.) ifade etmiştir. ${ }^{11}$

Hazar tarihi denilince ilk akla gelen isimlerden biri olan Artamanov'da "Pax Kharica" tabirine yönelik bazı çıkarımlarda bulunmuştur. Artamanov, Hazarların Arap saldırılarını

\footnotetext{
${ }^{4}$ Vasily Klyuçevskiy, Istoriya sosloviy v Rossii, Petrograd 1918, s. 39- 43.

${ }^{5}$ Mihaylo Gruşevskiy, Ístoriya Ukrainı i Rusi, T. I, 1904, s. 203; T. II, 1905, s. 500-530., Kiev. Hruşevsky'nin bu eseri için bk: http://litopys.org.ua/hrushrus/iur.htm, (E. T. 12. 5. 2019)

${ }^{6}$ Matvey Lyubavskiy, Lektsii po drevney russkoy istorii do kontsa XVI veka, Sankt-Peterburg 2000, s. 45.

${ }^{7}$ Yuriy Vladimiroviç Got’ye, "Hazarskaya kul’tura", Novly Vostok, No:8-9. Moskova, 1925.

${ }^{8}$ Peter Golden, "Khazar Studies: Achievements and Perspectives", The World of The Khazars, Vol. 17, Brill Pub., Leiden-Boston 2007, s. 24-26.

9 Ananiasz Zajaczkowski, "Khazarian Culture and its Inheritors", Acta Orientalia Academiae Scientiarum Hungaricae, Vol. 12, No. 1/3, 1961, s.300.

${ }^{10}$ Omeljan Pritsak, "The Khazar Kingdom's Conversion to Judaism”, Harvard Ukrainian Studies, Vol. 2., No.3, 1978, s. 261.

${ }^{11}$ A. g. m., s. 263-264.
} 
durdurarak, onların Bizans kültürünün kapılarını araladıklarından ve Hazar-Karadeniz civarında sağladıkları düzen ile (yani Pax Khazarica) ülkelerin ekonomisinin gelişimine ivme kazandırdıklarından bahsetmiştir. Fakat ona göre Hazarların böylesine olumlu bir siyaset güderken, Museviliği kabul etmiş olması devletle halkı koparan geri dönülmez ölümcül bir hataya sebep olmuştur. ${ }^{12}$

Yabancı tarihçilerin yanı sıra bizim tarihçilerimiz de "Pax Hazarika (Khazarica)" tabirini kimi zaman kullanmayı tercih etmiştir. Bu tabiri ilk kullananlardan biri olan İ. Kafesoğlu, Göktürk teşkilatını devam ettiren Hazarların hâkim oldukları sahada asayiş ve ulaşım güvenliğini temin ederek VII-IX. yüzyıllar boyunca, Doğu Avrupa'da Hazar Barışı (Pax Khazarica) çağı gerçekleştirdiklerini ifade etmiştir. Kafesoğlu'nun da daha çok bir politika olarak nitelendirdiği Hazar Barışı sayesinde, ulaşım ve mal mübadelesi arttırılarak doğudanbatıdan ticaret ve sanat erbabının kaynaştığı bir ülke haline gelmiştir. Aynı şekilde Hazar Barışı'nın sağladığı sükûnet ve huzurla gelişen ticari faaliyet, Rus-Slav Devleti'nin oluşumuna yardım etmiştir. ${ }^{13}$ Gerçekten de bu tespit oldukça yerindedir. Zira Hazarlar, Rusların ilerlemesi karşısında sessiz kalmış ve Dnyeper boylarındaki egemenliklerini tabiri caizse kendi elleriyle Ruslara vermişlerdir. Bu babda, Hazarlar tarafindan yürütülen müsamaha siyasetinin, devlet nezdinde ülkenin bekası için ne denli önemli olduğuna, A. T. Özcan farklı bir noktadan açıklama getirmiştir. Özcan'ın ifadesine göre Hazarlar, IX. yüzyılda Dnyeper Nehri'nin orta ve yukarı akımında Oleg liderliğinde devletleşen Rusların, bu bölgede bulunup da Hazarlara vergi ödeyen Slav kavimlerini kendine tabi hale getirmesine ve ticaret güzergâhları üzerindeki tehditkâr tutumlar sergilemesine karşı yukarıda da bahsettiğimiz gibi sessiz kalmıştır. İşte bu sessizliğin sebebi ona göre Dnyeper boylarındaki egemenliğin Pax Khazarica'ya kurban edilmesi ve İtil'in Dnyeper'e tercih edilmesidir ${ }^{14}$.

Günümüz tarihçilerinden olan ve Doğu Avrupa Türk tarihi ile ilgili çalışmalar yapan O. Karatay ise Hazarların hükmettiği alanın etnik yelpazesinin oldukça geniş olmasına karşın, kaynaklarda Hazarlara karşı çok fazla isyan girişiminin yer etmemiş olmasından ya da Hazarların askeri ihtiyaca çok fazla gerek duymamasından ötürü, onların Doğu Avrupa tarihi için ayrı bir yere oturtulması gerektiğini düşünmektedir. Aynı şekilde hükmettiği saha çerçevesinde demir yumruk kullanmakla birlikte, çok farklı inançtan ve dilden halk1 çok uzun süre idaresi altında tutmayı başarmış Hazarların bu durumunu, Roma ideolojisiyle ve Osmanlı uygulamalarıyla kıyaslanabilecek bir "Pax Khazarica" anlayışı ile açıklamakta bir sıkıntı doğmayacağını ileri sürmektedir. ${ }^{15}$

Yukarıda bahsi geçen tarihçilerin kullanmış oldukları şekliyle "Pax Khazarica", daha çok Hazarların uygulamış olduğu politika çerçevesinde değerlendirilmiştir. Kimi tarihçiler Pax Khazarica'yı, Hazarların hükmettiği sahada dinlere, dillere ya da milletlere gösterilen hoşgörü ile sınırlarken, kimi tarihçiler bu ifadeyi genel bir Hazar siyaseti olarak değerlendirmiş, Pax Khazarica eşittir Hazar politikası şeklini almıştır.

\section{Pax Khazarica'nın Oluşumuna Sebebiyet Veren Ekonomik Nedenler}

Hazarların hükmettiği sahada uzun yıllar hayatta kalabilmesinin en büyük sebebi kuşkusuz ki uygulamış oldukları hoşgörü eksenli politikaydı (Pax Hazarika). Fakat bu politikanın uygulanması arka planda bazı sebepleri barındırmıştır. Bu sebeplerin başında ise Hazar Hakanlığı'nın devlet hazinesinin dolmasına en büyük katkıyı sağlayan ticaret gelmiştir.

\footnotetext{
${ }^{12}$ Mihail İllarionoviç Artamanov, Hazar Tarihi-Türkler, Yahudiler, Ruslar, Çev: Ahsen Batur, Selenge Yayınları., İstanbul 2008, s.587.

${ }^{13}$ İbrahim Kafesoğlu, Türk Milli Kültürü, Ötüken Yayınları, 2010, s. 165-167.

${ }^{14}$ Özcan, a. g. e., s. 269.

${ }^{15}$ Osman Karatay, Hazarlar-Yahudi Türkler, Türk Yahudiler ve Ötekiler, Ankara 2015, s. 207.
} 
Hazar Hakanlığı’nın kurulduğu coğrafyanın müsaitliği sebebiyle, Hazar ekonomisinin temelini ticaret teşkil etmiştir. Hazarların Türkistan'dan İtil sahasına gelmelerinden bir süre sonra ağırlık merkezleri Terek'den Aşağı İtil'e doğru kaymıştır. Bulundukları coğrafya İtil, Yayık, Don ve Kuban gibi dört büyük nehrin havzasında bulunmakla birlikte, devrin en önemli ticaret yollarının da kesiştiği bir noktada yer almıştır. ${ }^{16}$ Doğu Avrupa'nın ticarî işlekliği için ayrı bir öneme haiz olan İtil Nehri'nin ulaştı̆̆ı ticarî noktalarda ise VII. yüzyıldan X. yüzyıla kadar özellikle Hazarlar, Ruslar ve Fin-Ugor kavimleri rol oynamıştır. Fakat Hazarların 630 yılında müstakil bir devlet haline gelmesinden sonra Karadeniz sahilleri, Kırım ve çevresi Hazarların eline geçmiştir.

1877 yılında Alman coğrafyacı tarafindan "İpek Yolu” adı verilen ve Çin'den Akdeniz’e doğru uzanan ticaret yolunun, güneye uzanan bu koluna alternatif bir kol olarak ortaya çıkan kuzey kolu, Hazar ticaretinde de ön planda olmuştur. Bahsi geçen bu kuzey kol Lob-nor (Lob Gölü)'dan Kuça ve Karaşar üzerinden Tanrı Dağları ve Tarım Nehri boyunca uzanıp, Kaşgar'a kadar gitmiş; oradan Fergana Vadisi'nden devamla Seyhun boylarına, devamında da Güney Yayık (Ural) bozkırları, Aşağı İtil bölgesine ve nihayet Karadeniz'in kuzey limanlarına ulaşmıştır. Bu yol neticesinde Avrasya sahasında yaşayan halklar ticaret vasıtasıyla Çin'den Avrupa'ya uzanan sosyal ve kültürel ilişkinin aracılığını yapmışlardır. ${ }^{17}$ İpek Yolu'nun kuzey kolu kendi içerisinde de belli başlı kollara ayrılmıştır: Büyük İtil Ticaret Yolu, Kama Ticaret Yolu, Bulgar-Kiev Ticaret Yolu ve Dinyeper Ticaret Yolu. ${ }^{18}$

Çin'den Akdeniz'e uzanan Büyük İpek Yolu'nun kuzeye uzanan kolu, güneye uzanan yolu kadar eski bir maziye sahip olmasa da, aktif olduğu dönem boyunca oldukça çetin mücadelelere sahne olmuştur. Özellikle IV. yüzyıldan itibaren Asya'dan batıya doğru gerçekleşen göçler neticesinde, Türk kavimleri tarafindan bellenen yol güzergahları ardından gelenlere her daim kolaylık sağlamıştır. Bu husus VI. yüzyılda İpek Yolu'nun kuzeyden denize ulaştırma amacıyla Kırım'a sefer düzenleyen Göktürk Kağanı'nın ${ }^{19}$ da bir dönem gündemini meşgul etmiştir. Fakat Göktürklerin VII. yüzyılın ilk yarısında yıkılmasıyla, onların başlatmış olduğu misyonu Hazarların devralmasına sebebiyet vermiştir.

Çin'de 907 yılında T'ang Hanedanı'nın yıkılması ile birçok Müslüman, Yahudi ve Hıristiyan'ın Çin'den sürülmesi üzerine İpek Yolu gerileme devrine girmiştir. ${ }^{20}$ Her ne kadar bahsi geçen kuzey yolunda bu tarihlerde, ticaret İtil Bulgarları ve Ruslar tekelinde gerçekleşmeye başlamış olsa da, ticaret yapma geleneği bu milletlere Hazarlardan miras kalmıştır. Özellikle VII-IX. yüzyıllar arasında en parlak devrini yaşayan Hazarların, hâkim olduğu sahalarda uygulamış oldukları ılımlı ticaret politikaları sayesinde her milletten ve dinden tüccar, Hazar topraklarında bulunan ticaret yolları üzerinde rahat bir şekilde ticaret yapma imkânına sahip olmuştur. Hazarlar bir yandan Karadeniz'in kuzeyi ve Kafkas sahillerini, öte yandan Yayık boyları ve Harezm Ticaret Yolunu kontrolü altında tutmuştur. Hazarların ele geçirdikleri sahaların genişlemesiyle, Hazar hâkimiyetinde tekelleşen bu ticaret yolları üzerinde kaleler inşa edilerek güvenlik sağlanmıştır. ${ }^{21}$ Tüm bu sebeplerden ötürü Hazar hâkimiyetinde bulunan Büyük İpek Yolu'nun kuzey kolu aktif olarak kullanılmaya

\footnotetext{
${ }^{16}$ Mualla Uydu Yücel, "Hazar Hakanlığı”, Türkler Ansiklopedisi, C. 2, Ankara 2002, s.446.

${ }^{17}$ Ekrem Kalan, "XIII-XIV. Yüzyıllarda Kuzey İpek Yolu ve Altın Orda Hanları'nın Ticaret Politikaları”, Avrasya Etüdleri Dergisi, S. 45, Ankara 2014, s. 46-47.

${ }^{18}$ Ekrem Kalan, "Velikiy Şelkovıy Put' i ego severnıe otvetvleniya”, Bulgarica (Vremya i prostranstvo Bolgarskoy tsivilizatsii atlas), R. S. Hakimov (Otv. Red.), Kazan 2012,s. 389.

${ }^{19}$ Altay Tayfun Özcan, Hazar Hakanlı̆̆ ve Etrafindaki Dünya, İstanbul 2019, s.27.

${ }^{20}$ Ahmet Taşağıl, “İpek Üretiminin Keşfi ve İpek Yolu'nun Başlaması”, İpek Yolu, Ahmet Taşağıl (Ed.), İstanbul 2015, s.24.

${ }^{21}$ Akdes Nimet Kurat, IV-XVIII. Yüzylllarda Karadeniz Kuzeyindeki Türk Kavimleri ve Devletleri, Murat Kitabevi, Ankara 1992, s. 33.
} 
başlanmıştır. Özellikle Müslüman Âleminin ihtiyaç duyduğu kuzey menşeli mallar (kürkler, deriler, balıklar vb.) bu yol hattı vasıtasıyla kuzeyden güneye taşınmıştır.

Hazarlar bu ticaret yolları sayesinde birçok milletten ve dinden tüccara ev sahipliği yapmıştır. Bu konu hakkında Arap kaynakları detaylı bilgi vermektedir. Örneğin İstahrî ve İbn Havkal, Hazarların Etil/İtil şehrine Rusların, Bulgarların ve Müslümanların ticaret yapmak için geldiklerini belirtmiştir. ${ }^{22}$ Yine İbn Hurdadbih de Rus tacirlerin izledikleri yolu tarif ederken Hazar ülkesini de bu yola dâhil etmiştir. ${ }^{23}$ Mesudî ise Hazar ülkesinde bulunan Rus tüccarların varlığı hakkında detaylı haberler vermiştir. ${ }^{24}$ Durum böyle olunca devlet sermayesi için büyük önem arz eden tüccarların milli ya da dini kimliği pek bir önem arz etmemiştir. Zira bu dönemde Araplarla girişilen askeri mücadeleler, her ne kadar Halifelik nezdinde dini amaçlı gösterilmiş olsa da bunlar dini bir mücadeleden ziyade, daha çok ekonomik nedenlerden dolayı gerçekleşmiştir. Hem Hazarlar hem de Araplar, Ortaçağda büyük önem arz eden ve devlet bütçesine ciddi katkılar sağlayan ticaret yollarının hâkimiyeti için uzun yıllar mücadele etmiştir. Kaynaklara yansıdığı kadarıyla dini kimlik, ticari konularda ikinci plana itilmiştir. Müslüman bir tüccar için samur kürkün putperest bir Slav'dan ya da bir Yahudi için necef taşının Yemenli bir Müslüman'dan satın alınmış olması herhangi bir sorun teşkil etmemiştir. Bu konu ile ilgili Mesudî, Hazar topraklarında yaşayan Müslüman ve Hıristiyanlar birleştikleri takdirde Hazarların onlara karşı gelinemeyecek kadar az sayıda olduklarını ifade etmesi ${ }^{25}$, konunun anlaşılabilmesi bakımından yeterli olacaktır. ${ }^{26}$

Hazarların, kendi ülkelerinde gerçekleşen ticaret sayesinde zenginleşmiş oldukları kaynaklara sıkça yansımıştır. Denizden ve karadan gerçekleşen ticaret çok geniş yelpazede yapılmıştır. Bu açıdan Hazarların uluslararası ticaretteki payı da hiç de azımsanmayacak ölçüde olmuştur. Öyle ki Hazar üzerinden kuzey ülkelerine giden İslam paraları İskandinavya'ya, oradan da İrlanda'ya kadar ulaşmıştır. İşte bu yoğun hareketlilikten, özellikle de deniz rüsumundan büyük kazançlar elde edilmiştir. ${ }^{27}$ Kaynakların da ihtiva ettiği gibi Hazar Hakanlığı, devletin tebaasından vergiler alan (büyük ölçüde Hazar dışından olan Müslüman tüccarlardan) ve değişik tüketim kalemlerinden gümrükler toplayan bir vergi toplama sistemine sahip olmuştur. Bununla birlikte Hazarların ihracatının çoğunlukla göçebe yaşam göstergesi olan sığır, koyun gibi hayvancılık unsurlarıyla sınırlı kalması ${ }^{28}$ ya da onların üretiminin zanaata dayanan malları içermemesi, birçok mal temini için dışa bağımlı olduklarını göstermektedir. $\mathrm{Bu}$ konu ile ilgili yorumda bulunan Dunlop'a göre, eğer Hazarlar daha fazla doğal kaynağa ve üretim gücüne sahip olabilmiş olsalardı, ancak o zaman Pax Khazarica'nın (politik ve ticari sistemlerinin canlı olmasını) devamlılığını sağlayabilirlerdi. ${ }^{29}$ Dunlop'un görüşü içerisinde bir takım kusurlar barındırsa da değindiği bir nokta haklılık payı taşımaktadır. Öyle ki değişik dinden ve milletten olan bir tüccara gösterilen hoşgörünün tek sebebi sadece ticaretin canlı tutulması, devlet kasasının dolması ya da mal sirkülâsyonunun sağlanması ile ilgili olmamıştır. Hazar ahalisinin ihtiyacının giderilmesi de bu tüccarlar vasıtasıyla sağlanmıştır.

\footnotetext{
${ }^{22}$ Ramazan Șeșen, İslam Coğrafyacılarına Göre Türkler ve Türk Ülkeleri, Ankara 2001,s.158 ve 167-168.

${ }^{23}$ İbn Hurdazbih,Yollar ve Ülkeler Kitabı, Çeviren M. Ağarı, Kitabevi Yayınları, İstanbul 2008, s. 130-131.

${ }^{24}$ Daniil Avraamoviç Hvol'son, İvestiya O Hozarah, Burtasah, Bolgarah, Madyarah, Slavyanah i Russah Abu- Ali Ahmeda Ben Omar İbn Dasta, Neizvestnogo dosele Arabskogo pisatelya naçala X veka,Po Rukopisi Britanskogo Muzeya. İzd. İmperatorskoy Akademii Nauk,. Sankt-Peterburg 1869, s.165.

${ }^{25}$ Şeşen, a. g. e., s. 47; Hvol'son, a. g. e., s.57-60.

${ }^{26}$ Karatay, a. g. e., s. 206.

${ }^{27}$ Osman Karatay, "Hazarlar”, Doğu Avrupa Türk Tarihi, Ed. Osman Karatay-Serkan Acar, İstanbul 2015, s.387.

${ }^{28}$ Peter Golden, Türk Halkları Tarihine Giriş, Çev: Osman Karatay, Ankara 2002, s. 198. Bu konu hakkında İstahri dty. bilgi vermiştir. Bk: Şeşen, a. g. e., s.157-159

${ }^{29}$ Boris Zhikhov, "The Khazar Economy: Economic Integration or Disintegration?". Khazaria in the Ninth and Tent Centuries, East Central and Eastern Europe in the Middle Ages, 450-1450, Vol.30, Brill Academic Publishers, 2015, s.174.:174.
} 
Pax Khazaricaa ile gelişen ticaret sayesinde sadece yönetici topluluğun seçkinleri zenginleşmemiştir. Pax Khazarica (kalıcı barış ve istikrar) sayesinde diğer halklardan kimseler de zenginleşmiş, her bir topluluğun üst ve yönlendirici tabakası bu zenginliğin ancak düzenin devamlılığılla sağlanabilecek olması gerektiği konusunda hemfikir olmuştur. Bu durum Karatay'ın deyimiyle Hazar sınırları içerisinde bir nevi Ortaçağ burjuvazisinin çıkar birliği etmesine benzeyen bir sistem oluşturmuştur. ${ }^{30}$

\section{Diğer Nedenler}

Hazar Hakanlığı kurulduğu coğrafya itibari ile çeşitli milletlerle uzun yıllar siyasi, askeri ve ticari ilişkiler tahsis etmiştir. Bu milletlerin en ön plana çıkanları ise Rumlar, İranlılar, Araplar, Ruslar ve değişik Türk kavimleri (Oğuzlar, Bulgarlar, Peçenekler, Kıpçaklar vb.) olmuştur. Zaten Hazarlar hakkında çoğu bilgiyi de (arkeolojik kaynaklar dışında) komşuları olan ve bir şekilde ilişkide bulunmuş oldukları Bizans, Gürcü, Ermeni, Eski Rus, İran, ve Arap yazılı kaynaklarından elde etmekteyiz. ${ }^{31}$ Bilindiği gibi Hazarların Kafkas bölgesine geliş serüvenleri bir anda değil, aşamalı gerçekleşmiş ve bu süreç yerleşimlerinden çok öncesine dayanmıştır. Bu sebeple yukarıda bahsi geçen milletlerle tanışıklığı uzun yıllara dayanmış, bölgedeki hâkim unsurların değişimi için gerekli olan tutumlara önceden aşina olmuşlardır. Onların siyasi ya da dini gelenekleri (ilk dönemlerde ve daha çok Hazar halkı arasında) her ne kadar bozkır yaşam tarzının hâkim olduğu İç Asya coğrafyasına dayanmış olsa da, tarım ve ticaret yapma yetenekleri daha çok Hazar-İtil sahalarına geldikten sonra kazanılmıştır. Bu sayede Hazarlar, hem göçebe hem de yerleşik yaşam tarzının kazandırmış olduğu yetilere aynı anda hâkim olabilmişlerdir. Yani bir devletin daha uzun ömürlü olabilmesi için nasıl bir yol izlenmesi gerektiği konusunda uzmanlaşmışlardır. Fakat zaman içerisinde eski Türk konar-göçer hayat tarzından sıyrılarak yerleşik hayat tarzına geçişleri yoğunlaşmıştır. Bu durumun oluşmasında birçok faktör etkili olsa da bizim için üzerinde durulması gereken konu, onların ilişkide bulundukları milletlerle neden barışsal bir politikayı (Pax Khazarica) esas aldıklarıdır.

Hazarlar tarafından bir devlet politikası halini alan "Pax Khazarica"nın işlerlik kazanmasının arka planında yatan unsurlardan birini de siyasi ilişkiler oluşturmuştur. Bizans ve Sasanilerin, daha da önemlisi Sasanilerin dinamik takipçisi Arap halifeliğinin sınırlarında bulunan Hazar Hakanlığı, Akdeniz dünyasının en büyük iki yerleşik gücü ile yakın temas halinde olmuştur. ${ }^{32}$ Özellikle Arap Halifeliğine istinaden Bizans'la daha dostane ilişkiler kurmasının bazı sebepleri olmuştur. Fakat bu dostane ilişkiler her iki devletin de çıkarları neticesinde gerçekleşmiştir.

Bu babda iki devlet arasında kurulan ilk ilişki Sasanilere karşı ittifak olarak gerçekleşmiştir. 626 yılında Bizans imparatoru Herakleios ve Kağan Ziebl'in Tiflis'te tanışmaları sonucunda gerçekleşen bu ittifak neticesinde, 627' de Sasanilere karşı Nineveh Savaşı gerçekleşmiştir. ${ }^{33}$ Hazarların Bizans'a yapmış olduğu bu askeri yardım neticesinde bölge coğrafyasında neredeyse yeni bir dönem başlamıştır. Zira Hazarların sayesinde İran gibi köklü bir devleti yenmeyi başaran Bizans, aynı dönemde başşehirlerine saldıran Avarları da ağır bir yenilgiye uğratmıştır. ${ }^{34}$ Neredeyse bir asır sonra Justinianos'un tahttan indirilmesiyle (711) Bizanslı yöneticilerle, dostane ilişkiler kurmaya devam eden Hazar Hakanlığı, bu tarihten sonra savaş meydanlarında çoğu kez Bizans'ın yanında yer almıştır. ${ }^{35}$ Zira Bardanes'in tahttan

\footnotetext{
${ }^{30}$ Karatay, a. g. m., s 208.

${ }^{31}$ Gennady Afanes'yev, "O territorii Hazarskogo Kaganata i Hazarskogo <Domena> v IX Beke". Divnogorskiy Sbornik, Vipusk 6, 2016, s. 41.

${ }^{32}$ Golden, a. g. e., s. 195.

${ }^{33}$ Kevin Alan Brook, Bir Türk Imparatorluğu Hazar Yahudileri, Nokta Kitap, 2005, s. 259.

${ }^{34}$ Georgiy Ostrogorsky, Bizans Devleti Tarihi, Çev. Fikret Işıltan,Türk Tarih Kurumu Yayınları, Ankara 2011, s. 97.

${ }^{35}$ Brook, a. g. e., s. 261.
} 
indirilmesinden sonra tahta geçen bir başka Ermeni asıllı imparator III. Leon ( 717-741) döneminde Hazarlarla ittifak noktasında önemli bir adım yaşanmıştır. İmparatorun oğlu V. Konstantinos Hazar Hakanı'nın kızı Çiçek ile evlendirilmiştir. ${ }^{36}$ Hazarlar tarafından bu evlilik, Araplarla savaş halinde olan Bizans ile bir dostluk ve ittifak mesajı olarak gerçekleşmiştir. Hazar-Bizans münasebetlerinin yoğun yaşandığı VIII. yüzyılda, imparatorlar Hazar hakanına üç mühürlü mektup göndererek, onlarla olan akrabalık bağlarından istifade etmiş, kendi siyasi ve askeri meselelerinde onların yardımlarına başvurmuşlardır. Yine bu dönemde Hazar askerleri, İstanbul'a getirilerek imparator saraylarının korunmasında kullanılmışlardır ${ }^{37}$.

Yukarıda verilen örnekler çoğaltılabilmekle birlikte Bizans açısından, Hazarlarla neden barışçıl ilişkiler kurulması gerektiği sorusuna tatmin edici cevaplar vermesi açısından yeterlidir. Bizans, gerek iç gerek ise dış meselelerde giriştiği çoğu mücadelede Hazarlardan askeri olarak faydalanmıştır. Bu sebeple uzun bir süre komşuları olan Hazarlara siyasi ve askeri müttefiklik açısından muhtaç olduğunun farkında olmuştur. Peki Hazarların, Bizans ile dostane ilişkiler kurmasının sebeplerini neler oluşturmuştur?

Hazarlar, sınırları içerisinde yaşayan Ortodokslara müsamaha göstermek suretiyle Bizans siyasetinde etkili olmak istemiştir. ${ }^{38}$ Zira Hazarlar dönem dönem hem siyasi hem de ekonomik olarak komşuları olan Bizans'a sırtını dayamıştır. Bu konu ile ilgili verilebilecek en bariz örneği Sarkel Kalesi oluşturmaktadır. 835 yılında Hazar hakanı düşman saldırılarına karşı, Sarkel kalesinin yapımı için Bizans'tan yardım talebinde bulunmuştur. Konstantin Porphyrogennetos'un "De Administrando Imperio" adlı eserinde belirtildiğine göre bu kale Hazar hakanın ricası üzerine Bizans tarafından yaptırılmıştır. İmparator, Theophilus, Petronas ve Paphlagonia idaresindeki yardımcıları Sarkel şehrini imar etmeleri için bölgeye sevk etmiştir. ${ }^{39}$ Kalenin inşa edilmesinin ortak amacı, Orta Don bölgesinin kontrol altında tutulmak istenmiş olmasıdır. Bu bölgenin kontrol altına alınması hem Bizans'ın hem de Hazar Hakanlı̆̆g'nın sınırlarının güvenliği için büyük önem arz etmiştir. ${ }^{40}$ Şehrin yerinin tam olarak tespit edilememiş olmasına karşın, bölgede yapılan kazılarda ortaya çıkan delillere göre Peçenek ve Uzların bu bölgeye akınları söz konusu olmuştur. ${ }^{41}$ Bu akınların önlenmesinde Bizans, Hazarlara hem maddi yardım sağlamış hem de müttefiklik etmiştir.

Hazar-Bizans ilişkileri "Pax Khazarica" çerçevesinde değerlendirildiğinde diğer milletlerle kurulan ilişkilerde olduğu gibi yine ticari çıkarlar ön plana çıkmıştır. Araplar vasıtasıyla ellerine geçen çok çeşitli malları, Azak üzerinden İstanbul'a getiren Hazarlar, Rumlarla çok sıkı ticari ilişkiler tahsis etmiştir. Örneğin X. yüzyılda Kurtuba Halifesi III. Abdurrahman nezdindeki Bizans sefirleri, Hazar'dan gelen gemilerin İstanbul'a balık, kürk vs. getirip, kumaş alarak geri döndüklerinden bahsetmiştir. ${ }^{42}$

Hazarların, Bizans ile dostane ilişkiler kurması yukarıda da bahsedildiği gibi, her iki devletin de karşılıklı çıkarlarının sağlanması noktasında gerçekleşmiş olduğunu söyleyebiliriz. Hazarlar siyasi ve ekonomik olarak Bizans'a muhtaçken, Bizanslılar çoğunlukla askeri olarak Hazarlara muhtaç olmuştur. ${ }^{43}$ Hazarların, Araplarla ilişkilerine baktığımızda ise dostane

\footnotetext{
${ }^{36}$ Karatay, a. g. e., s. 142.

${ }^{37}$ Ali Ahmetbeyoğlu, Sorularla Eski Türk Tarihi, İstanbul 2014, s. 220.

${ }^{38}$ Lev Nikolayeviç Gumilev, Hazar Çevresinde Bin Yll, Selenge Yayınları, İstanbul 2002, s. 212.

${ }^{39}$ Konstantin Porphyrogenitus, De Administrando Imperio, Çev: Romilly Jenkins, Washington 1985, s. 183.

${ }^{40}$ Artamanov, a. g. e.,s. 387.

${ }^{41}$ Kurat, a. g. e.,s. 34.

${ }^{42}$ Wilhelm Heyd, Yakın Doğu Ticaret Tarihi, Çev: Enver Ziya Karal, Türk Tarih Kurumu Yayınları, Ankara 2000,s. 54 .

${ }^{43}$ Valery Naumenko, "Vizantiysko-Hazarskie otnoşeniya v seredine IX. veka" Hazarı. Evrei v Slavyane Tom 16. Moskova 2005, s. 231.
} 
ilişkilerden çok, askeri mücadeleler göze çarpmaktadır. Bu durumun en büyük sebebi, İslamiyet'in yeni zuhur etmiş bir din olması sebebiyle yayılma sürecine girmiş olmasıdır. Özellikle Emeviler döneminde, Kafkaslara gerçekleştirilen askeri seferler yoğunlaşmıştır. Ticaretin kuzeyden güneye, güneyden kuzeye akışı için çok önemli bir mevkie sahip olan Derbend, İslam ordularının da dikkatini çekmiştir. Halifelik orduları her ne kadar İslam dinini yaymak amaçlı Kafkaslar üzerine sefer yaptığını ilan etmiş olsa da, yapılan seferlerin asıl amaçlarından birini ticaret yollarının ele geçirilmesi oluşturmuştur. Bu sebeple, Hazarların Müslümanlardan ziyade Halifelik ordularına bakışı hiç de dostane olmamıştır. ${ }^{44}$ Oysaki "Pax Khazarica" çerçevesinde Hazarların diğer dinden olanlara olduğu gibi Müslümanlara da bakış açısı iyimser olmuştur. Hatta kaynaklara yansıdığ 1 üzere, Hazar yurdunda hâkim unsuru Müslümanlar oluşturmuş ve Hazar ordusunda yer almışlardır; Müslümanlar için mescitler, camiler inşa edilmiş, ezanın okunmasına ise karışılmamıştır. ${ }^{45}$ Buradan yola çıkarak Müslümanların, İslam beldelerinde bulamadıkları birçok hususu ya da huzuru Hazar yurdunda bulmuş olabileceği yorumunu yapmak hiç de abartılı olmayacaktır. Zira bölgede bulunan İslam cemaatlerinin yoğunluğu ve bahsi geçen dini yapıların varlığı da göz önüne alındığında, Müslümanların Hazar yurduna isteyerek göç ettiğini söyleyebiliriz. Mesudî’nin de Arsiyye/Arsi Müslümanları ve diğer Müslümanların, Hazar Hakanının sağlamış olduğu adalet ve güvenlikten dolayı buraya göçtüklerini belirtmiş olması ${ }^{46}$ önceki tespitimize dayanarak olarak gösterilebilir.

Hazar Hakanlığı, bünyesinde çeşitli etnik toplumların bir araya gelmesini sağladığı için, sağlam bir polietnik sistem üzerine devlet oluşumlarını gerçekleştirmişlerdir. Devletleşme süreçlerinde, özellikle komşularının dini inançlarına hoşgörüyü, diğer Türk kavimlerinde olduğu gibi ön planda tutmuşlardır. Örneğin Hazar'ın dağlık Dağıstan sınırı üzerinde ve Belencer'de, Hazarlar Albanlarla dostane ilişkiler kurmuş, Çir-yurt bölgesindeki kiliseler çoğu kez müttefikleri olan Bizans-Ortodokslarına değil, Monofist Hristiyanlara ait olmuştur. ${ }^{47}$ Hazar bünyesinde bununla birlikte Ortodoks Rumlar, Nestorikler, Müslümanlar, Fin ve Slav inançları da yer almıştır. Hazar Hakanlığı hâkimiyetinde yaşayan farklı inanç ve kültürden halklarla ilgili doğulu kaynaklar ayrıntılı bilgiler vermektedir. ${ }^{48}$

Hazarların devlet oluşumlarında ve daha sonrasında dinlere göstermiş oldukları bu müsamaha, aslında etnik sistemin çok çeşitli olduğu topraklarda devletleşme aşamasına giren ve bölgede kalıcı olmak isteyen her milletin kaçınılmaz olarak izlemesi gereken bir politikayı oluşturmuştur. Bunu stratejik bir şekilde uygulamasını bilenler uzun süre hayatta kalmayı başarabilmişken, bilemeyenler tarih sahnesinden kısa süre zarfında silinmişlerdir. Örneğin Doğu Avrupa Hun lideri Attila, devletleşme sürecinde İtil'den Ren Nehri'ne kadar tüm kavimleri (Ostrogotlar, Gepidler, Herullar, Rugiler, Bulgarlar, Romalılar, Grekler vb.) sancağ 1 altında toplamayı başarmıştır. Düşmanlarına karşı sert ve acımasız olan Attila, himayesi altında yaşayanlara karşı hoşgörülü ve adaletli olmuştur. ${ }^{49}$ "Pax Khazarica" ibaresinin mahiyeti bakımından örnek verilmesi gereken bir başka Türk Devleti, XIII. yüzyılın sonu XIV. yüzyılın başında kurulan Osmanlı Devleti'dir. Onlar da askeri fetihler neticesinde hâkim olduğu sahalarda kalıcı olabilmesini fethettiği topraklarda yaşayan halkların dinine, diline ve milliyetine göstermiş olduğu hoşgörüye borçludur. Aslında klasik İslam fütuhat anlayışıyla bu

\footnotetext{
${ }^{44}$ Ahmetbeyoğlu, a. g. e., s. 212-216.

${ }^{45}$ Şeşen, a. g. e.,s. 46.

46 Mesudî, Muruc Ez- Zeheb (Altın Bozkırlar), Çev: Ahsen Batur, Selenge Yayınları, İstanbul 2004, s. 70-71; Karatay, a. g. m., s. 383.

${ }^{47}$ Gumilev, a. g. e., s. 211.

${ }^{48}$ Hvol'son, a. g. e.,s. 17, 57, 165; İbn Fadlan Seyahatnamesi, Çev: Ramazan Şeşen, İstanbul 2015, s. 47; Mesudi, $a$.

g. e., s.70; Şeşen, a. g. e., s. 36, 157-158, 167.

${ }^{49}$ Gumilev, a. g. e.,s. 180
} 
bakımdan ters düşen Osmanlılar, ilk etapta fethettikleri bölgenin İslamlaşmasından ziyade elde ettikleri zenginlikler ve yayıldıkları stratejik mevkiler ile ilgilenmişlerdir*.

Hazarlarda insanlara gösterilen hoşgörünün ağırlıklı olarak nedenlerini siyasi, askeri ve ticari hususlar oluşturmuş olsa da, bilinen bir hakikat vardır ki, o da Türk kavimlerinin dini inançlara karșı olan ilgisidir. Bu durumda Türk kavimlerinin geniș bir coğrafyaya yayılmıș olması da etkili olmuştur. Türk kavimleri ilk dinleri olan Gök-Tengri'den ziyade Budizm, Maniheizm, İslamiyet, Hristiyanlık, Musevilik gibi dinlere de ilgi duymuşlar, kimi zaman devlet çatısı altında kimi zaman da ferdi olarak bu dinlerin inananları arasında yer edinmişlerdir. Tarihi kayıtlara göre de Gök-Tengri'ye inanan Hazarlar, daha sonra Hristiyanlık, Musevilik ve İslamiyet ${ }^{50}$ ile de karşılaşmışlardır. Hazarlar her ne kadar Museviliği devlet dini olarak benimsemiş olsa da Hazar halkının çoğunluğunu, faklı dinden olan kimseler oluşturmuştur. Belki de tarihte eşine az rastlanır olan bu durum ( yönetici ve halk arasındaki inanç farkının bu denli yoğun olması) ilk etapta seküler açıdan çok olumlu bir hava yaratmış gibi gözükse de, sonradan devletin parçalanma sürecine girmesinde büyük etkiye sebep olmuştur. Öyle ki bir süre sonra Hazar topraklarında yaşayan Hristiyanlar, Müslümanlar ve Gök-Tengriciler, Musevi Hazar yönetimi tarafından güç kullanılarak itaat altına alınmıştır. Artamanov'un deyimiyle nevi şahsına münhasır Musevilik inancı, geniş kitlelerin devlet dinine girmesine izin vermemiş, tebaayı sadece ebedi haraç güzar kulları olarak görmüştür. ${ }^{51} \mathrm{Bu}$ durum da halkın isyan girişimlerini beraberinde getirmiştir.

\section{Pax Khazarica Politikasının Sonuçları Nedir?}

Hazarların sosyal ve siyasi geleneklerinin bir yansıması olan Pax Khazarica İtil Bulgarlarına, Kievli Ruslara, Macarlara ve Kafkas bölgesi halkların X. yüzyıldan XIII. yüzyılın ilk yarısına yani Moğol istilasına kadar Doğu Avrupa'da politik, askeri ve ekonomik olarak güçlenmesine büyük katkı sağlamıştır. V. V. Grigoryev, Hazar Hakanlığı ile ilgili önemli saptamalarda bulunmuştur. Ona göre Ortaçağ'da müthiş bir fenomen olan Hazarlar, göçebe ve vahşi halklarla çevrili olmasına ${ }^{*}$ rağmen, eğitimli tüm ülkelerin avantajlarına sahip olmuştur: yerleşik bir devlet şekli, kapsamlı ve gelişmekte olan ticaretin yanı sıra düzenli birlikler. Anarşi, bağnazlık ve cehalet Batı Avrupa'da hâkimken, Hazar Hakanlığg adalet ve dini hoşgörü ile ün salmıştır. Bu yüzden inançları yüzünden zulüm gören herkes Hazar yurduna kaçış yolu aramaya başlamıştır. Hazar Hakanlığı, canlı bir örnek olarak Avrupa'nın karanlık ufkunda parlamıştır. $^{52}$

Pax Khazarica'nın dezavantaj ya da avantaj olarak nitelendirilmesi Hıristiyan ya da Müslüman dünyasınca farklı yorumlanabilecek bir sonucu daha bulunmaktadır ki, mahiyeti bakımından oldukça önemlidir. Slav ve Ortodoks gözüyle bakıldığında olumlu, Müslüman âleminin gözüyle bakıldığında olumsuz bir netice olan bu husus İslamiyet'in Doğu Avrupa'ya yayılmasının engellenmiş ${ }^{53}$, Slavların ise yeni bölgeleri sömürgeleştirilmesinin önünün açılmış olmasıdır. Barışçıl politikalar ve farklı kültürlere karşı gösterilen hoşgörü sayesinde Ruslar

\footnotetext{
* Bahsedilen bu husus Osmanlı'nın kuruluş evresine dairdir. Dty. Bl. Bk: Feridun Emecen, "Osmanlılarda Gaza Anlayışını Yeniden Düşünmek”, İlk Osmanlılar ve Batı Anadolu Beylikler Dünyası, 2012, s. 127-140.

${ }^{50}$ Yücel, a. g. m., s. 450-463.

${ }^{51}$ Artamanov, a. g. e., s. 532.

* Burada kastedilen Hazarlarla soydaş olan Oğuz, Peçenek gibi Türk kavimleridir. Hazarların medeni, bu Türk kavimlerinin ise vahşi olarak telakki edilmesi yazarın bakış açısı ile ilgilidir. Oysaki Hazarların da göçebe bir kültüre sahip olduğu bilinmektedir.

52 Bulat Khamidullin, "Pax Khazarica: A View from the 21. Century". Studia et Documenta Turcologica, 3-4, 20152016:117-118.

${ }^{53}$ Victor Shnirelman, "The Story of Euphemism: The Khazars in Russian Nationalist Literature”. The World of The Khazars, Vol. 17, Brill Pub.,Leiden-Boston 2007, s. 370.
} 
(tüccarlar başta olmak üzere) zengin kültür kaynakları ile tanışmış, Hazarlardan politika yapmayı öğrenmişlerdir.

Hazar yurdunda, devletin her milletten ve her inançtan halka aynı müsamahayı göstermesi, zaman içerisinde farklı algılara yol açarak iç çatışmalara yol açmış, her dinin mensubu ülkeye kendi dindaşlarının hâkim olması için faaliyet göstermiştir. ${ }^{54}$ Belki de Pax Khazarica'nın kesin olarak bilenen en olumsuz sonucunu da bu oluşturmuştur.

\section{KAYNAKÇA}

AFANAS'YEV, Gennady, “O territorii Hazarskogo Kaganata i Hazarskogo <Domena> v IX veke”. Divnogorskiy Sbornik, Vipusk 6, 2016, s. 41- 72.

AHMETBEYOĞLU, Ali, Sorularla Eski Türk Tarihi, İstanbul 2014.

ARTAMANOV, Mihail İllarionoviç, Hazar Tarihi Türkler, Yahudiler, Ruslar, Selenge Yayınları, İstanbul 2008.

BROOK, Kevin Alan, Bir Türk Imparatorluğu Hazar Yahudileri, Nokta Kitap, İstanbul 2005.

CAMPBELL, Brian, "Roma Dünyasında Diplomasi (Yaklaşık M. Ö. 500-M. S. 235)", Tarih Okulu, İlkbahar-Yaz 2013, S. XIV, Çev: Recep Özman, 2013, s.201-224.

EMECEN, Feridun, İlk Osmanlılar ve Batı Anadolu Beylikler Dünyası. İstanbul 2012.

GOLDEN, P., Türk Halkları Tarihine Giriş, Çev: Osman Karatay, Karam Yayınları, Ankara 2002.

GOLDEN, Peter, "Khazar Studies: Achievements and Perspectives". The World of The Khazars, Vol. 17, Brill Pub.,Leiden-Boston 2007, s.7-58.

GOT’YE, Yuriy Vladimiroviç, “Hazarskaya Kultura”. Novıy Vostok, 1925.

GRUŞEVSKIYY, Mihailo, Istoriya Ukrainı i Rusi, T. I (1904); T. II (1905).

GUMILEV, Lev Nikolayeviç, Hazar Çevresinde Bin Yıl, Çev: Ahsen Batur, Selenge Yayınları, İstanbul 2002.

HEYD, Wilhelm, Yakın Doğu Ticaret Tarihi, Çev: Enver Ziya Karal, TTK Yayınları., Ankara 2000.

http://litopys.org.ua/hrushrus/iur.htm. (E.T. 12. 5. 2019).

http://www.kulichki.com/inkwell/text/special/history/kluch/kluchlec.htm. (E. T. 12.5.2019).

https://history.wikireading.ru/92465. (E. T. 12. 5. 2019)

HVOL'SON, Daniil Avraamoviç, İzestiya O Hozarah, Burtasah, Bolgarah, Madyarah, Slavyanah i Russah Abu- Ali Ahmeda Ben Omar Ibn Dasta, Neizvestnogo dosele Arabskogo pisatelya naçala X veka,Po Rukopisi Britanskogo Muzeya, İzd. İmperatorskoy Akademii Nauk,. Sankt- Peterburg 1869.

İbn Fadlan Seyahatnamesi, Çev: Ramazan Şeşen, Yeditepe Yay., İstanbul 2015.

İBN HURDAZBİH, Yollar ve Ülkeler Kitabl, Çev: Murat Ağarı, Kitabevi Yay., İstanbul 2008.

KABAAĞAÇ, Sina- ALOVA, Erdal, Latince Türkçe Sözlük, Sosyal Yayınları, 1995.

${ }^{54}$ Yücel, a. g. m., s. 445-63. 
KAFESOĞLU, İbrahim, Türk Milli Kültürü, Ötüken Yayınları, İstanbul 2010.

KALAN, Ekrem, “XIII-XIV. Yüzyıllarda Kuzey İpek Yolu ve Altın Orda Hanları'nın Ticaret Politikaları", Avrasya Etüdleri Dergisi, S. 45., Ankara 2014, s. 43- 62.

KALAN, Ekrem, "Velikiy Şelkovıy Put' i ego severnıe otvetvleniya”, Bulgarica (Vremya i prostranstvo Bolgarskoy tsivilizatsii atlas), R. S. Hakimov ( Otv. Red.), Kazan 2012.

KARATAY, Osman, "Hazarlar”, Doğu Avrupa Türk Tarihi, Ed. Osman Karatay- Serkan Acar, İstanbul 2018, s.335-408.

KARATAY, Osman, Hazarlar-Yahudi Türkler, Türk Yahudiler ve Ötekiler, Ankara 2015.

KHAMIDULLIN, Bulat, "Pax Khazarica: A View from the 21. Century". Studia et Documenta Turcologica, 3-4, 2015-2016, s.117-130.

KLYUÇEVSKIY, Vasily, İstoriya sosloviy v Rossi, Petrograd 1918.

KLYUÇEVSKIY, Vasily, Kurs Russkoy istorii, T. 1, Moskva 1990.

KURAT, Akdes Nimet, IV-XVIII. Yüzylllarda Karadeniz Kuzeyindeki Türk Kavimleri ve Devletleri, Murat Kitabevi Yayınları, Ankara 1992.

LYUBAVSKIY, Matvey, Lektsii po drevney russkoy istorii do kontsa XVI veka, SanktPeterburg 2000.

MESUDÎ, Muruc Ez-Zeheb (Altın Bozkırlar), Çev: Ahsen Batur, Selenge Yayınları, İstanbul 2004.

NAUMENKO, Valery, "Vizantiysko-Hazarskie otnoşeniya v seredine IX. veka", Hazarı. Evrei v Slavyane, Tom 16. Moskova 2005.

OSTROGORSKY, Georgiy, Bizans Devleti Tarihi, Çev: Fikret Işıltan, TTK Yayınları, Ankara 2011.

ÖZCAN, Altay Tayfun, Hazar Kă̆anlı̆̆ ve Etrafindaki Dünya, İstanbul 2019.

PORPHYROGENITUS, Konstantin, De Administrando Imperio, Çev: Romilly Heald Jenkins), Washington 1985.

PRITSAK, Omeljan, “The Khazar Kingdom's Conversion to Judaism”, Harvard Ukrainian Studies, Vol.2, No.3., 1978, s.261.

SHNIRELMAN, Victor, "The Story of Euphemism: The Khazars in Russian Nationalist Literature", The World of The Khazars, Vol. 17, Brill Pub.,Leiden-Boston 2007, s.353-372.

ŞEŞEN, Ramazan, İslam Coğrafyacılarına Göre Türkler ve Türk Ülkeleri. TTK Yayınları, Ankara 2001.

TAŞAĞIL, Ahmet, “İpek Üretiminin Keşfi ve İpek Yolu'nun Başlaması”, İpek Yolu, A. Taşağıl (Ed.), İstanbul 2015, s. 13- 28.

WOOLF, Greg, "Roman Peace". War and Society in the Roman World, Vol.5, LondonNewyork 2002, s.171-194.

YÜCEL, Mualla Uydu, "Hazar Hakanlığı”, Türkler Ansiklopedisi, C.2., Ankara 2002, s. 445463.

ZAJACZKOWSKI, Ananiasz, "Khazarian Culture and its Inheritors", Acta Orientalia Academiae Scientiarum Hungaricae, Vol. 12, No. 1/3 (1961), s. 300. 
ZHIKHOV, Boris, "The Khazar Economy: Economic Integration or Disintegration?", Khazaria in the Ninth and Tent Centuries, East Central and Eastern Europe in the Middle Ages, 450-1450, Vol.30, Brill Academic Publishers, 2015, s.174. 